IRA-International Journal of Management \& Social Sciences

ISSN 2455-2267; Vol.03, Issue 03 (2016)

Institute of Research Advances

http://research-advances.org/index.php/RAJMSS

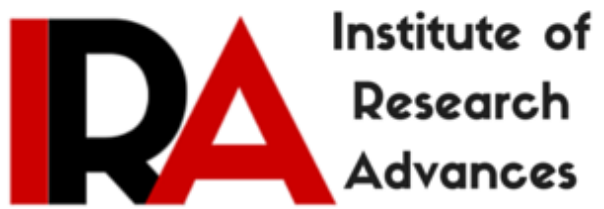

\title{
Review of Literature for Models of Foreign Financial Institutions (FFIS) Financing Business \& Trade
}

\section{Ashok Vasant Edurkar}

Commerce \& Management Department, Shivaji University, Kolhapur, India.

DOI: http://dx.doi.org/10.21013/jmss.v3.n3.p17

\section{How to cite this paper:}

Vasant Edurkar, A. (2016). Review of Literature for Models of Foreign Financial Institutions (FFIS) Financing Business \& Trade. IRA-International Journal of Management \& Social Sciences (ISSN 2455-2267), 3(3). doi:http://dx.doi.org/10.21013/jmss.v3.n3.p17

(C) Institute of Research Advances

\section{(cc) EY-NO}

This works is licensed under a Creative Commons Attribution-Non Commercial 4.0 International License subject to proper citation to the publication source of the work.

Disclaimer: The scholarly papers as reviewed and published by the Institute of Research Advances (IRA) are the views and opinions of their respective authors and are not the views or opinions of the IRA. The IRA disclaims of any harm or loss caused due to the published content to any party. 


\section{Introduction:-}

The model from strategic point of view is defined as a collection of financial business specific decisions that develop and/or maintain competitive advantage. So far as financing of India's Foreign Trade is considered, the FFIs model for financing Foreign Trade is a totally new approach towards the financial system and foreign trade analysis. Earlier researchers employed the FFIs model analysis approach towards the analysis of financial system. The FFIs model analysis offers a wide range of applications. Several authors already employed this type of analysis, generating promising results. FFIs model is an important tool displaying the essence of financial business practices that lead to profits. Nevertheless, only well-defined FFIs model provides the information necessary to identify, compare and possibly enhance a certain trait. The FFIs models topic is often debated in the latest financial literature. The concept is used as an educative and analytical tool to explain and understand how FFIs function. The term model is widely applied and capable of including a range of financial business aspects. Financial business objectives, core customers, product management, financial business strategies, organization infrastructure and many other strategic and operational business processes fit in FFIs model term. Because of this capability to explain so much, FFIs model term suffers an "identity crisis". Independent analysis undertaken by scholars and their individual approach towards business practices investigation resulted in a broad range of diverse interpretations and definitions in existing literature. While scholars do not agree what a model is, certain patterns are available and definitions emerge. This review of literature is presented here as under:-

1 With the application of specific models by financial institutions, the question is whether financial development precedes or simply follows economic growth along with foreign trade growth. A general proposition states that the development of the financial sector is expected to have a positive impact on economic growth along with foreign trade growth. The theoretical relationship between financial development and economic growth goes back to the study of Schumpeter (1911) who focuses on the services provided by financial intermediaries and argues that these are essential for innovation and development to result into economic growth.

2 This explanation was originally advanced by Robinson (1952). All these views are based on the observation that the ratio of the broad money stock to nominal GDP, which is a standard measure of financial development used in the literature, is also the inverse of the velocity of circulation of the broad money stock. Hence, a positive correlation between the level of financial development and the real GDP may be due to a downward trend in the velocity of money circulation. If this is true, then the positive relationship between financial development and real GDP may reflect an income elasticity of the demand for money with respect to income, which is greater than one. Consequently, according to this argument the direction of causality will be from real GDP to financial development and that through the demand for money.

3 The new interest in the determinants of economic development has reignited the debate on openness and growth. In neoclassical growth models developed by Solow (1957), technological change is exogenous variable - unaffected by a country's degree of openness of the economy. Yet the new growth theories suggest that Foreign Trade policy affects long-run growth through its impact on technological change. In these models, the degree of openness of the economy provides access to imported inputs, which embody new technology (Harrison 1996). The concept of openness, applied to Foreign Trade policy, can be synonymous with the idea of neutrality. Neutrality means that incentives are neutral between saving a unit of foreign exchange through import substitution and earning a unit of foreign exchange through exports. Clearly, a highly export oriented economy may not be neutral in this sense, 
particularly if it shifts incentives in favor of export production through instruments such as exports subsidies.

4 Mckinnon, Shaw (1973) examine the impact of government intervention on the development of the financial system. Their main proposition is that government restrictions on the financial system such as interest rate ceilings and direct credit programs have negative effects on the development of the financial sector and, consequently, reduce economic growth. The endogenous growth theory has reached similar conclusions by explicitly modeling the services provided by financial intermediaries such as risk-sharing and liquidity provision.

5 Summers, Heston (1988) points out that other studies attempting to explain the causal relationship between the degree of openness of the economy and economic growth end up with mixed results.

6 Edwards (1992), points out that studies focusing on the theory of Foreign Trade and growth have shown that there is a positive relationship between Foreign Trade and economic growth.

7 Harrison (1996) states that a good measure of Foreign Trade policy will capture the differences between neutral, inward oriented and export-promoting regimes. The simplest measures of Foreign Trade orientation are based on actual trade flows, such as imports plus exports as a share of GDP or the growth rates of imports and exports.

8 Ghali (1999) states that this theory also suggests that financial intermediation has a positive effect on steady-state growth and that government intervention in the financial system has a negative effect on economic growth. A theoretical view claims that financial development follows economic growth as a result of increased demand for financial services.

9 Shan, Morris, et al. (2001) use a Granger causality procedure to investigate the relationship between financial development and economic growth for nine OECD countries and China by estimating a vector auto-regression (VAR) model. The results of their study show that five out of ten countries have a bilateral Granger causality; three of them have reverse causality with economic growth leading to financial development while two countries do not have a causal effect at all.

10Arestis, Demetriades ,et al. (2001) examine the relationship among stock market development, credit market development and economic growth, utilizing time series methods and data from five developed countries. The results of their paper suggest that bank-based financial systems may be more able to promote long run growth along with Foreign Trade growth than capital-market-based ones

11 Sinha, Macri (2001) examine the relationship between financial development and economic growth for eight Asian countries, which are divided in two categories. The first includes seven developing countries while the second one includes only Japan. The aim of their study is to investigate through a multivariate causality test if there are differences between financial development and economic growth for both examined categories. The empirical results are mixed, namely there is a bilateral causal relationship between the examined variables for India, Malaysia,and Sri Lanka, a unidirectional causal relationship between financial development and economic growth for Japan and Thailand, while they find reverse causality, namely from economic growth to financial development for Korea, Pakistan and Philippines. 
12 Srinivasan (2001) states that Indian exchange rate policies achieved significant depreciation of the rupee for some time against major currencies as the latter floated against each other. The depreciation, coupled with deliberate export promotion (or at least reduction of bias against exports), led to Indian exports to grow faster on an average than world exports (in volume) since 1973. Still in value terms, India's share in world merchandise exports, which stood at $2.1 \%$ in 1951 , declined to $0.4 \%$ in 1980 and recovered since only to $0.7 \%$ in 2000 .

13 Shan and Morris (2002) adopt the Toda, Yamamoto's (1995) model and by using quarterly data for the period 1985-1998 investigate the causal relationship among the following variables: real GDP, ratio of total credit to GDP, spread of borrowing and lending interest rates, productivity, ratio of gross investment to GDP, ratio of total trade to GDP, consumer price index, official interest rate, stock market price index for 19 OECD countries. They conclude that financial development leads to economic growth either directly or indirectly through the remaining examined variables. As far as Greece is concerned, the authors suggest that no causal relationship between financial development and economic growth is found for the examined period 14 Evans, Green, et al (2002) evaluate the contribution of human capital and financial development to economic growth in a panel of 82 countries using the trans log production function as a framework for estimating the relationships among economic growth and factor inputs such as labor, physical capital, human capital and monetary factor (money or credit). The results of their paper suggest that financial development is as important as human capital in the growth process.

15 Deidda, Fattouh (2002) present a simple model, which establishes a nonlinear relationship between financial development and economic growth, based on a threshold regression model of King and Levine's study (1993a). The results of their paper suggest that in low-income countries there is no significant relationship between financial development and economic growth, whereas in high-income countries this relationship is positive and strongly significant.

16 Nourzad (2002) examines the effect of financial development on productive efficiency using three separate panels of developed and developing countries. The results indicate that the more financially developed economy, the more efficient the production of output. This effect appears to be larger in developed countries relative to the developing ones.

17 Carmen, Teresa (2002) presents in their article some econometric models which take into account both supply and demand sides as determinants of real Exports, including the important relationships existing between industrial development and external trade. The models focus on the positive role human capital plays in reducing external debt by fostering the evolution of exports and allowing the increase of imports necessary for industrial development. The analysis is performed with data of 25 OECD countries during the period 1960-97.

18 Donald, Morgan, et al. (2003) state that across countries internationally, the benefits of foreign entry seem to depend on the level of development, but at least for developing nation's entrants are more efficient than incumbent FFI and the stiffer competition seems to improve overall FFI efficiency. In contrast to these first-order effects, the stability implications of increased entry are less obvious. This paper investigates whether greater integration resulting from foreign bank entry has been associated with more or less business cycle volatility. They approach the topic with mix of theory and evidence from both the U.S. states and countries. While theoretical effects are mixed, the empirical effect of relaxation of restrictions of cross-state financing has been to stabilize state-level fluctuations in the U.S. Applying a related 
set to a panel of about 100 countries, however, they find no evidence that expansion of foreign banking has reduced business fluctuations. If anything, the evidence points tentatively in the other direction.

19 Magretta (2002) presents the model concept through an evolutionary view. His explanation is based on innovativeness developing new models and optimal exploitation of the models that already exist, but could bring higher value. In his words, "..., a successful model represents a better way than the existing alternatives". In his study, the author introduces well-known companies and their success stories, implying the value of innovative and unique models (e.g. American Express traveller checks), as well as the benefits of better utilised, existing models (e.g. Wal-Mart perfecting existing model of a discount store).Magretta further expands the topic by discussing the adoptability of existing models. He urges to question the suitability of the performing model in a different environment (e.g. Disney World in Europe). Here, a diversity of external factors is described as a necessity for consideration before and after model introduction. In author's words - "Modelling is the managerial equivalent of the scientific method - you start with a hypothesis, which you then test in action and revise when necessary".

20 Shafer, Smith et al. (2005) and (Casadesus-Masanell, Ricart 2010) introduced the analogue view towards the model as a reflection of an entity's realized strategy. Financial Business strategy as a term is often used as a synonym for the model. Although both terms in a financial business environment often share a similar ultimate objective - sustainable profitability - they are not the same thing. The model is a system based on representation of financial business elements fitting together in an attempt to grasp a viable financial opportunity. Despite portraying a financial business "recipe", it does not account for a critical performance dimension competition. Considering a profitable financial business in real market conditions, the occurrence of competition is just a matter of time. As per Magretta (2002) it is the strategy's task to obtain and maintain the frontrunner position. In other words, the financial business strategy represents a custom implementation of the model with anticipation towards inevitable competition. On the other hand, a new model that introduces radical changes in a financial system and is difficult to replicate can become a competitive advantage by itself. (Magretta 2002, Casadesus-Masanell, Ricart 2010). Beside the concerns for competition, a strategic point of view towards models emphasizes generated value beneficiaries' satisfaction. A model, if looked at from this point of view, has to account for two sides of the financial business beneficiaries: customers and shareholders. It defines value sharing and delivery processes, ensuring mutual satisfaction. Never the less, an increasing tendency for customer focused value creation is observed (Chesbrough, Rosenbloom 2002). Economic consideration of models relies on logic that generated value (profit) in a financial institution directly represents the performance of the model. Here, as well as in strategic considerations of a model, competition plays an important role. Scholars embrace the idea that the performance of a model is highly affected and depends on its competitiveness. A conceptual attempt to explain a firm's performance through the model in a competitive environment was suggested by A. Afuah, who identified the model as a set of components utilised to achieve profit - a measurement of performance (Afuah 2004). He created a strategic model framework of profit determinants, which should be manipulated to reach the best performance. Seeking a more tangible outcome, a number of scholars conducted an empirical analysis, which incorporated similar conceptual logic.

21 Umakrishnan, Bandyopadhyay, (2005) investigate the relationship between the changing patterns of bank's source of income and risk adjusted performance. A database of 77 banks over the period of 1999 to 2004 is constructed for the 27 public 
sector banks, 22 private banks, 25 foreign banks and 3 cooperative banks to compare their change in income composition. Bank's performance is measured by risk adjusted return on BIS risk allocated capital (RARORAC). To examine the relationship between ownership pattern and performance, we compare the difference between new generation private sector banks and foreign banks with their public sector and cooperative banks counterparts. We argue that in a competitive financial market in order to change the profitability drivers in banking, Indian banks need to improve their non-interest income and also augment risk adjusted interest income through better risk based pricing.

22 Another model definition tendency, which primarily focuses on the identification of the actions taken and methods adopted within the business, largely falls under the component consideration approach. Here, the totality of the components and their interrelations form the model. The well-structured definition based on the component consideration is provided by (Osterwalder, Pigneur et al. 2005) "A business model is a conceptual tool containing a set of objects, concepts and their relationships with the objective to express the business logic of a specific firm". Authors partially treat the model as an analysis tool. They attempt to conceptualize models, to separate associated definitions and to structure the terminology for the purpose of future topic development.

23 Lehner, Schnitzery (2006) FFI entry is frequently associated with spillover effects for local financial institutions and increasing competition in the local financing market. They study the impact of these effects on host countries. In particular, they ask how these effects interact and how they depend on the competitive environment of the host banking market. An increasing number of financial institutions is more likely to have positive welfare effects, the more competitive the market environment, whereas spillovers are less likely to have positive welfare effects the stronger competition. Hence, competitive effects seem to reinforce each other, while spillovers and competition tend to weaken each other.

24 Bremner , Knipfer, et al. (2006) proposed model wherein they state that By "operating model," they mean the way people, technology, and processes interact to deliver a common objective, as well as where these resources are located and who owns them (exhibit). The term can be applied very broadly - to a finance function, to a pharmaceutical company, to a university. In financial organizations, it would include processes such as claims underwriting, trade execution, and settlement. In this article, they have shown how some financial institutions, by rethinking all the elements of an end-to-end process, are beginning to realize enormous benefits compared with others that focus on only one or two elements of the process- such as offshoring certain tasks without considering interactions with technology or potential process improvements.

25 The role of FFIs is vital and tends to elevate the efficiency and working system of the local financial system by introducing sophisticated financial services. As per Benson Kunjukunju (2006) while making a strong case in favor of financial sector liberalization, its proponents claim that the entry of FFIs in the poor and developing world is highly desirable and beneficial.

26 Zott, Amit (2007) analyzed models and their performance within entrepreneurial firms. The authors' analytical approach towards the relationship of the models and the firm's performance rely on two distinct effects: the value generating potential of an employed model and a firm's ability to absorb generated value. They identify efficiency and novelty representing the two major axis, affecting the outcome which 
results from their definition of model as a set of boundary-spanning transactions with external parties. The authors treat the model as an independent variable, which translates to performance. Environmental factors take the role of value-effecting dependent variables.

A later publication by Zott, Amit (2008) introduced a new study which further focused on models and firm performance relation. Questioning the effects of the model and the product market strategy interactions impact on a financial firm's performance, Zott and R. Amit examine a suspected contingency effect. The contingency theory suggests that there is no optimal strategy for all firms and that the desired choice of strategy variables is altered according to contingency factors. In this case, a firm's model is treated as a contingency factor. Through the use of a purpose developed formal model and contingency theory, authors investigate a collected data set. Findings suggest "those novelty-centered models - coupled with product market strategies that emphasize differentiation, cost leadership, or early market entry can enhance firm performance". The authors formulate that both the model design and product market strategy function complimenting each other, not substituting. This particular interpretation of the model offers a wide applicability in empirical studies related to certain market model analysis. Innovation in a model design is yet another factor showing high influence to overall financial firm performance.

27 Richardson (2008) explains how firm activities function together under the intended model, and at the same time, he formulates strategy as the process of model implementation.

28 Loechel, , Li (2009) attempt to shed some light on business models by conducting a comparative study based on data of banks from China, Europe, the UK and the USA. The analysis reveals that that the profitability of Chinese banks is mainly bolstered by the still guaranteed interest margin set by the central bank. Moreover, the risk pricing mechanism in loan business as evident in Western peer banks is not yet established well in China's banking sector. Therefore, the diversification in fee and commission income is most important for Chinese banks to leverage their competitiveness. The high concentration of the current revenue sources on lending in Chinese banks cannot sustain if the interest margin narrows in a more liberalized interest and exchange rate environment. The equity participating of Chinese banks in asset management companies shows already first results in generating synergies in terms of scale and scope.

29 Rezvaniana, Raoa, et al. (2008) state in their study which uses a nonparametric frontier approach to examine the effects of the ownership on the efficiency, efficiency change, technological progress and productivity growth of the Indian banking industry over the period 1998 to 2003. A host of best practice frontiers are constructed relative to which the performance of foreign-owned banks, private-owned banks and public-owned banks operating in India are assessed. The results indicate that foreign banks are significantly more efficient when compared to other banks, i.e. the privately-owned and publicly owned-banks.

30 Guisan, Maria et al. (2008) analyze economic development in Philippines for the period 1990-2006, with special focus on inter-sectoral relationships and the role of foreign trade. They analyze the evolution of real value added of Agriculture, Manufacturing, Industry and Services, and present an econometric model which shows the important and positive impact of manufacturing and foreign trade on economic development.

31 Uppal (2009) state that there is an enunciation of the need to channelise the flow of credit to certain sectors of the economy, known as the priority sectors, in the 
largest interest of the country, can be traced to the Reserve Bank's credit policy for the year 1967 - 1968. The government initiated measures for social control over banks in 1967 - 1968 with a view to securing a better adaptation of the banking system to the needs of economic planning and it is playing a more active role in aiding sectors like agriculture and small scale industries (SSIs). The present study is an attempt to study the priority sector advances by the public, private and foreign bank groups. This study is based on the parameters like lending to priority sector by public, private sector and foreign bank groups, targets achieved by public, private sector and foreign bank group NPAs (Non-performing assets), while lending to priority sector. On the basis of these parameters, the study concludes that public sector banks have not achieved the target of $40 \%$ while private sector banks have achieved the overall target. No private sector bank could achieve the $10 \%$ target by lending to weaker section. On the other hand, foreign banks have achieved the small scale industries' export credit and overall target. NPAs of public sector banks have increased because of high priority sector advances. The paper also throw light on the problems or issues which arise due to priority sector advances and also suggest some strategies to sought out these issues. All the parameters have been analyzed for the period, 2006 - 2007.

32 Uppal (2010) attempted to study the trends in non-interest income which is a vital source of stability in bank income. For this, the study takes some parameters like interest and non-interest income as a percentage to total income, share of non-interest income components like exchange \& brokerage, sale in investment and exchange transaction. On the basis of these parameters the study concludes that interest income is continuously declining due to deregulation in interest rates and non-interest income is rising. Among the non-interest income components, commodity exchange \& brokerage witnessed a large share while exchange transaction witnessed a meager part. The paper also gives some ways and means to bring stability in the total income

33 Gormley (2010) in his paper uses the entry of FFIs into India during the 1990sanalyzing variation in both the timing of the new FFIs' entries and in their locationto estimate the effect of FFIs' entry on domestic credit access and firm performance. In contrast to the belief that foreign bank entry should improve credit access for all firms, the estimates indicate that FFIs financed only a small set of very profitable firms upon entry, and that on average, firms were 8 percentage points less likely to have a loan after a FFIs entry because of a systematic drop in domestic institution loans. Similar estimates are obtained using the location of preexisting foreign firms as an instrument for FFIs locations. Moreover, the observed decline in loans is greater among smaller firms, firms with fewer tangible assets, and firms affiliated with business groups. The drop in credit also appears to adversely affect the performance of smaller firms with greater dependence on external financing. Overall, this evidence is consistent with the exacerbation of information asymmetries upon FFIs entry.

34 Ghosh (2012) states that the analysis related to FFIs suggests that FFIs penetration improves profitability and asset quality, although it dampens spreads. The results are robust to alternate measures of FFIs presence. In addition, FFIs appear to impact the maturity of credit portfolio of domestic institutes. Finally, the results also support the fact that FFIs typically charge lower interest rates as compared to domestic institutes.

35 Rakhe (2010) states that the study on FFIs assumes importance in the context of the on-going preparation of roadmap for the presence of FFIs in India, as per the study conducted by the RBI, results of which indicate that access to low cost funds, diversification of income, adequate other income to fully finance the operating expenses are the important factors leading to the higher profitability of foreign banks vis-a-vis other bank groups in India. The results of the panel data regression also 
indicate that efficiency of fund management is the most important factor determining profitability in the system followed by generation of other income. However, with regard to the FFIs policy, a holistic view may be taken by considering factors such as global financial inter-linkages, financial performance of parent institution as also the pursuit of social objectives by these institutions.

36 Cull, Peria (2010) conclude in research paper that most developing countries around the world have seen an increase in foreign financial institution (FFI) participation since the mid-1990s. However, this process has not been uniform. While regions like Eastern Europe, Latin America, and Sub-Saharan Africa quickly welcomed and promoted foreign entry, Asia and the Middle East have been latecomers to this process and so far have only partially opened up their financial sectors. This paper has reviewed these trends and attempted to condense and draw conclusions from the existing evidence on the drivers and consequences of FFIs entry. When it comes to the drivers of FFIs participation, there is little doubt that the search for profit opportunities, the elimination of barriers to entry, and the presence of factors that help mitigate the information costs of operating in foreign markets have played a key role in promoting FFIs participation in developing countries. On the other hand, the evidence on the consequences of FFIs participation is less clear cut. Overall, their reading of the literature is that FFIs entry has enhanced competition and stability in developing countries, but the impact on access to finance is less clear and needs to be explored further.

37 Hryckiewicz, Kowalewski (2010) state that in the last two decades, FFIs have significantly expanded their presence in several emerging markets. The expansion of FFIs has continued despite the global financial crisis. In the study they establish the role of economic factors and their relevance in driving a FFI's expansion decision into emerging markets. The results confirm that the economic factors influencing the location choice of FFIs vary with respect to the economic condition of the home and host countries. Moreover, the results show that these factors may influence a FFI's choice of organizational structure in emerging markets.

38 Vogel, Winkler (2010) state that FFIs have increased their market share in many emerging markets since the mid-1990s. They examine whether this contributed to financial stability in the respective host countries in the global financial crisis. Their results suggest that the stabilizing impact of FFIs was limited to the cross-border component of financial globalization and to two regions: Eastern Europe and SubSaharan Africa. Only in the latter region was this translated into more stable credit growth. Thus hopes that a stronger presence of FFIs might help host countries in isolating domestic credit from international shocks did not materialize in the global financial crisis.

39 Osterwalder, Pigneur (2010) introduce the concept of model in their book "Business Model Generation" through the generalized view of 470 practitioners from a number of different countries. Authors define the business model as a representation of how organization creates, delivers and captures value. They use models in an attempt to better explain how firms do business. Additionally, the book offers downto-earth explanations and numerous practical examples aimed at educating new generation entrepreneurs. Identifying decision making as an essential part of the model formation, some scholars turned to a managers' perspective (George, Bock 2011). In search of a better model conceptualization, the study analyses existing literature and few surveys of practicing managers. Findings point to the opportunitycentric model perspective, which is based on resource transference and value structures. Here, the model is a design of organizational structure with the purpose of seizing a commercial opportunity. 
40 Besides the obvious economic value, some models can be intended for social value objectives. For example, non- profit organizations and some state- or privatelyowned firms develop their models optimized for social value (e.g. reduction of poverty of famine, increase in living standards).MacMillan and Thompson studies social value implications in models and suggest a framework for social value optimized model development (MacMillan, Thompson 2010). Though not essential, social value consideration became a certain norm in new models. As discussions about social inequality are becoming more frequent, society expects successful firm's contribution to social wealth. In turn, observable and well-advertised social value contributions often result in additional benefits for the firm (e.g. an increasing number of customers and loyalty). Further analysis through value consideration suggests that the previous frameworks are not capable of recognizing the total value generated by models (Amit, Zott 2001). As a response to these findings, the authors of the study introduce potential sources of value creation through models. They list novelty, lock-in, complementarities and efficiency as main drivers, and at the same time, implying complimentary properties of individual value drivers. An additional argument is presented by G. Hamel, who suggest that a substantial share of value creation as well as absorption occur in the value network, consists of financial business related parties and structures (e.g. suppliers, distribution networks) (Hamel 2000).

41 Olsen (2010) states that the banks are important facilitators of international trade. Besides providing liquidity they guarantee payment for around a fifth of world trade, in particular when the contract enforcement of the importing country is weak. But if contract enforcement is too weak to trust the payment of an importer, why trust the importer's bank? It is argued that reputational mechanisms can provide the answer. Weak contract enforcement introduces a limited-enforcement problem, as the importer can renege on payment after receipt of the shipment, which repeated interaction alleviates. For importers too infrequently engaged in international trade to establish a credible reputation, a bank can increase credibility by guaranteeing multiple importers, but only if exporters can collectively punish the bank should it renege on one of them. Mutually agreed bank guarantees to overcome the need for collective punishment and further increase credibility as bilateral claims between banks reduce the net amount to be reneged on. While this paper focuses on banks, reputational mechanisms can also shed light on both large intermediaries and export credit agencies.

42 Shah (2010) et al state that financial inclusion will be meaningless unless the rural economy is stimulated and rural infrastructure is developed. Banks' initiatives have to be supplemented with comprehensive public sector initiatives for rural infrastructure development. There is a gap in India's financial services institutional framework for an institution that can play a pivotal role in financing rural infrastructure with sufficient government backing. NABARD could be repositioned for this role.

43 George, Bock (2011) seconds the evolutionary thinking regarding the model, and stresses the fact that organizations adjust and redesign their models under the effects of changed operational environment.

44 Altunbas, Manganelli, et al. (2011) exploit the 2007-2009 financial crisis to analyze how risk relates to financial institutions' business models. Institutions with higher risk exposure had less capital, larger size, greater reliance on short-term market funding, and aggressive credit growth. Business models related to significantly reduced institute's risk were characterized by a strong deposit base and greater income diversification. The effect of business models is non-linear: it has a different impact on riskier banks. Finally, it is difficult to establish in real time 
whether greater stock market capitalization involves real value creation or the accumulation of latent risk.

45 Pradhan, 2011) states that from being one of the prime opponents of the inclusion of services in the UR negotiations, India has of late emerged as a leading proponent of the services trade liberalization under the GATS. The focus of services trade has shifted from facilitating trade in goods to trade in services as an independent entity in itself with the four modes of supply for the delivery of services in cross-border trade.

46 Loechel,, Sottocornola (2011) state that Different FFIs run according to different business models. Of special interest is the comparative analysis of business models between FFIs in developed and developing countries. This paper compares the evolution and current status of business models of Bank of China and Deutsche Bank, both before and after the recent financial crisis. It shows that the mix between commercial and investment banking activities in both banks moved from opposite polarities towards a more similar business model. This process reflects the efforts of Bank of China to become an internationally-recognized investment bank, while Deutsche Bank rebalances its business model in the direction of commercial banking activities. Driving forces of these initiatives are the changing markets and regulatory environments in which the banks operate.

47 Bhat (2011) state that by and large, Indian manufacturing industry has remained on the periphery of globalization. India has not taken the advantage of international segmentation of production process which has reshaped the industrial specialization of many countries in Asia. India's foreign trade in manufacturing underwent limited structural changes over the last twenty years or so but it is still based on traditional complementarities. Exports are still heavily dominated by labor-intensive products, characterized by a slow growing international demand and protected markets. The technology content of India's trade is low by international standards, but it has built up a strength in technology niches. India's high-tech manufactured exports are concentrated in chemical and pharmaceutical industries. The export competitiveness in pharmaceutical products is based on strong domestic capacities to assimilate and replicate foreign technology and on its endowment in skilled labour. Besides, India has made a breakthrough in international trade in IT and software services and is now competing with developed countries. In contrast with Asian latecomers, India's hightech exports rely mainly on domestic technical capabilities and on local human capital, and not on assembly of high-tech components into final products.

48 Lin (2011) in his paper studies the impact of FFIs entry on domestic firms' access to bank credit using a within-country staggered geographic variation in the policy of foreign bank lending in China. The paper finds that after foreign bank entry profitable firms use more long-term bank loans; whereas firms with higher value of potential collateral do not. It also finds that non-state-owned firms become able to substitute some trade credit with long-term bank loans. The findings suggest that less opaque firms and non-state-owned firms benefit more from foreign bank entry and that collateral may only play a limited role in mitigating the problem of information asymmetry when creditors' rights are not well protected in a host country.

49 Despite such a rich diversity in the model definition approaches and themes, one major tendency is commonly observed. No matter which approach is taken to define the model, it always builds up to a major consideration - value preposition (Amit, Zott 2011). In their recent study, Zott and Amit used a sample of 103 reviewed publications to classify the model concepts and derive commonly observed themes. The authors managed to provide a well- structured version of the model literature overview and, similar to other scholars, recognize that value creation, transformation 
and capture are at the core of every model. In other words, the purpose of the model is seen as value achieved through a firm's performance and competitiveness. David W. Stewart and Qin Zhao support this definition in their study, concluding that "simply defined, a model is a statement of how a firm will make money and sustain its profit stream over time". The model definition considerations through strategic, technological or competitive approaches, all rely on generated value as an indication of the model performance. The ability to measure and compare performance in recognizable units of value (usually money) is the intended benefit of such reliance. Value creation, though often interpreted as a simple profit, can refer to different forms of value.

50 Ayadi et al. (2011) discuss the effects of the financial crisis by deriving models from a sample of 26 European financial institutions. A follow-up study of Ayadi et al. that was published in 2012 employs similar techniques but uses a bigger European financial institutions sample and focuses primarily on the impact of financial regulations. A similar study aimed towards European financial institutions' model identification is published by Ferstl ,Seres, (2012) who used a large financial institutions sample but showed a specific interest towards Austrian financial institutions. All these previous studies show a variety of applications and even variations in the methodologies used; however; only European financial institutions were analyzed in specific settings, thus allowing for further studies to be conducted.

51 Arshad, Isaksson (2012) focused their study on BRIC countries only which are the fastest growing developing countries. Second, this study compared foreign bank's profitability with domestic bank's profitability. Whereas, return on assets and return on equity was used as an indicator of profitability. Nearly 1600 bank's financial data was collected from Bankscope database and Thomason Reuter's DataStream. The current Study followed a Quantitative research method in order to investigate two research questions; first was the impact of foreign bank's profitability on domestic bank's earnings during 2001-2011 and second was foreign and domestic bank's financial performance during financial crisis. Hierarchical multiple regression in the absence of control variables (foreign bank's market share, inflation rate, real interest rate and GDP growth rate) explained that foreign banks were positively related with domestic banks in BRIC during 2001-2011. This Study rejected previous research results that foreign banks had negative relation with domestic banks in developing countries. Second result showed that in fast growing developing countries like Brazil, Russia, India and China, domestic banks performed better than foreign banks during financial crisis whereas foreign bank's profitability had high volatility then domestic banks in financial crisis.

52 Walter (2012) Financial regulatory reforms. What it means for bank business models, Regulators across the globe are moving forward to implement levels. While the main pillars of the reforms appear settled, many of the details regarding national implementation of regulations, such as Basel III, the Dodd-Frank Wall Street Reform and Consumer Protection Act in the US and, in the European Union (EU), the Capital Requirements Directive the implications of the reforms for their business models, structure and operations. Nevertheless, enough is now known about the new regulatory landscape for banks to think strategically about the aggregate impact and to consider the effects of regulatory changes in the broader context of efforts to reshape and strengthen the business. To help banks as they assess how the changing global regulatory landscape affects them, Ernst \& Young has established the Global Regulatory Network, which brings together former senior regulators across its global practices. Our global regulatory services are led by an executive team of former senior regulators, including members of the Basel Committee on Banking Supervision and the European Banking Authority. This team drives Ernst \& Young's 
strategic outlook on the global regulatory themes affecting our clients, including capital, liquidity, resolution and recovery planning, risk governance and other emerging topics in banking regulation. This paper presents an overview of the global regulatory reform agenda and the impact it will have on banks' business and operating models.

53 Gupta, Aggarwal (2012) state that under World Trade Organization (WTO), the opening of the Indian banking sector fully to the foreign players will pose a keen competition for the banks in India. Under Commercial presence (Mode 3) of General Agreement on Trade in Services (GATS), foreign banks with branch presence were allowed Foreign Direct Investment (FDI) in private sector banks in 2005. These developments have a tremendous impact on overall functioning of Indian banks and enhancement of competition. The objective of the study was to assign ranks to different bank groups on the basis of their overall performance scores. The study concludes that although foreign banks and new private sector banks (modern) were significantly better than the public sector banks and old private banks (traditional) but the traditional banks had improved their performance post WTO. This study will hopefully claim the attention of our policy makers, bankers, corporate executives and other interested parties.

54 Ayadi et al. (2012) have presented research report which provides four key findings. These findings are as follows:-

a) It adds a new category of business models to the three previously identified, namely: 'diversified retail banks' (using diversified sources of funding and providing predominantly customer loans).

b) It provides evidence that diversified retail and retail- focused business models are clearly safer than others, as measured by the distance from default (Z-score), amount of loss absorbing capital and the long-term liquidity risks (NSF ratio).

c) In line with the previous study, it also confirms that investment-oriented banks seem to engage in regulatory arbitrage to reduce their risk-weights without shedding any risks.

d) The research report highlights a certain discrepancy between declared intentions and practice within the EU banking industry. Although banks such as BNP Paribas, Deutsche Bank or Société Générale define themselves as retail-oriented institutions for marketing purposes, the research report provides indeed evidence that their business model is in fact closer to investment banking.

55 Onaolapo, Odeyemi (2012) state that their studies have confirmed strong and positive correlation between finance sources and the performance of agricultural sectors. However the shift of the Nigeria Government attention to oil sector after her independence has caused a major setback in the finance of agriculture and agro allied industries. The thrust of this study is to investigate the relationship between available forms of finance and performance of cocoa processing firms in Lagos State, Nigeria. The study used purposive sampling technique to select six (6) out of eleven (11) intermediate cocoa processing firms identified on the registered list of Nigerian Export Promotion Council (NEPC) in south western part of Nigeria. The Pearson correlation analysis conducted indicated that there is strong association $(\mathrm{R}=0.916)$ between the two main variables of cocoa export performance and available forms of finance. From the regression analysis, it was discovered that available forms of finance were able to account for up to $84 \%$ changes $(\mathrm{R} 2=0.840)$ in cocoa export performance of Nigerian intermediate cocoa firms. While the funds sourced through commercial banks inform of loans have strong effect on the changes in the performance of intermediate cocoa processing firms in Nigeria, retained profits have an effect that can be described as moderate. The contribution of funds sourced from NEXIM banks in a form of loan was less than satisfactory. The study suggested that 
Policy makers should route their intervention funds/assistance to agricultural sector through commercial banks for effectiveness but that interest rates charged by these commercial banks should be well monitored and controlled

56 Morgan (2013) in his paper assesses the case for FFIs as part of a program of institutional reform geared toward export promotion in emerging market economies. It does so by empirically evaluating the impact of FFIs participation on the export performance of emerging market firms. It hypothesizes that FFIs participation will not have a statistically significant moderating effect on the anticipated positive relationship between firm size and export sales. Using an unbalanced panel of 930 firm-year observations for Indian chemical firms over the period 1997-2005, it employs the two-stage least squares (2SLS) method with fixed effects to estimate a simultaneous equations model. The empirical evidence suggests that higher foreign bank participation in the domestic banking sector may attenuate the positive firm size-export sales relationship; however, this mediating effect is not significant in both statistical and economic terms.

57 Liston, Prairie (2013) state that approximately 80 percent of global trade relies on some version of trade finance. They seek to further the understanding of the relationship between trade flows and the availability of trade finance, while accounting for the development of the sample countries' financial sectors. The model also controlled for additional established variables that significantly influence trade patterns, such as import/export demand and exchange rates. The results indicate that trade finance is a positive correlate with export and import volumes. However, researchers also found that trade finance becomes even more important in determining trade volumes when countries have a higher level of financial development.

58 Topalova, Khandelwal (2010) exploit in their research paper India's rapid, comprehensive and externally-imposed trade reform to establish a causal link between changes in tariffs and firm productivity. Pro-competitive forces, resulting from lower tariffs on final goods, as well as access to better inputs, due to lower input tariffs, both appear to have increased firm-level productivity, with input tariffs having a larger impact. The effect was strongest in import-competing industries and industries not subject to excessive domestic regulation. While we find no evidence of a differential impact according to state-level characteristics, we observe complementarities between trade liberalization and additional industrial policy reforms.

59 Viorica (2013) aim in their paper to analyze the foreign trade efficiency for Romania and compare it with the other E.U. member states. They use stochastic frontier analysis to estimate the efficiency component of foreign trade of Romania and EU countries. We built 27 econometric models, one for each country, considering EU members trade partners units plus eight extra-EU partners. They estimated the 27 member countries' efficiency coefficients associated with each partnership. These coefficients were used to estimate the average efficiency scores for each of the 27 countries. The analysis results have shown that the economic crisis hasnot significantly changed trade patterns and hierarchies between EU countries, only lowered trade performance.

60 Contessi, Nicola (2013) state that the recent financial crisis has focused attention on the relationship between access to finance and international trade, triggering a burgeoning segment of the literature evaluating this link empirically. We review the role of finance in international trade and the main theories connecting them. Moreover, we provide a structured road map to recent empirical studies while 
summarizing what we have learned to date about this relationship. We separately analyze studies that rely on aggregate, industry-level, and firm-level data, emphasizing the differences between those that analyze ordinary times and those that focus on banking and financial crises. We discuss the role of diverse measures of access to finance, financial health, and financial vulnerability along with the key challenges in estimating the relationship between trade and finance. We conclude that once the heterogeneity of methodologies and measures of access to and dependence on finance is accounted for, the empirical literature suggests an important role for finance in determining export participation at the extensive margin but weaker results for the intensive margin of trade. Moreover, while empirical studies tend to favor a causal relationship moving from finance to trade, there is some evidence suggesting causality moving in the opposite direction, which merits further investigation.

61 Wignall , Roulet (2013) attempt to model the Distance-To-Default (DTD) of a large sample of banks with the aim of shedding light on policy and regulatory issues. The determinants of the distance-to-default in a panel sample of 94 banks over the period 2004 to 2011, controlling for the market beta of each bank, included house prices, relative size, simple leverage, derivatives Gross Market Value (GMV) of exposure, trading assets, wholesale funding and cross-border revenue. The Basel Tier 1 ratio found no support as a predictor of default risk. The un-weighted leverage ratio, on the other hand, found strong support. At the macro level house prices are a powerful predictor of the DTD. At the business model level, the results appear to be consistent with an approach to policy that focuses on the apparent importance of the "size-derivatives leverage and wholesale funding' nexus in influencing the DTD of banks. While these results are preliminary, it was encouraging that the out-of-sample predictive power of the model improves systematically as each year of new observations is added. The results are also consistent with some central bank involvement in the supervision process, given the importance of the asset price cycle, identified in this study.

62 Ahrend, Goujard (2013) state that the spreading of the 2007-09 global financial crises has highlighted the need to increase the resilience of the financial sector to contagion shocks. Debt financed by FFIs has been found to increase the financial fragility of the borrowing country in situations of financial contagion, but effects could differ with the structure of the financial sector in the borrowing country. Using bilateral financial flows over the 1983-2011 period, they show that external financial flows towards foreign-controlled FFIs have been more stable than flows towards domestically-owned institutions and firms during financial contagion shocks.

63 Srivastaw (2013) investigated the performance of selected foreign and new private sector banks using certain financial performance indicators. Descriptive statistics and paired $t$ test have been employed to analyse and to draw the conclusion. The study makes use of secondary data. The relevant data has been collected through the Statistical Tables Relating to Banks in India, Trend \& Progress of India, various published reports and other studies. Performance has been compared by dividing the total study period into two parts viz. Supra and Umbra periods. The study shows that the asset qualities of the banks shows improving trends throughout the study period both in respect of Foreign Banks as well as in respect of New Private Sector Banks. It has also been found that both Foreign Banks and New Private Sector Banks improved the quantum of priority sector lending in the Supra period by taking advantages of the existing provisions.

64 Earnest \& Young (EY) report 2013 states that from the perspective of 2013 it is clear that a number of business models across large parts of the banking industry. Which products and services are capable, under the new regulatory regimes coming 
into force, of generating a sustained return above a now much higher cost of equity? How can banks completely transform their cost bases, and hence core processes, to realign their business models to the new normal? What are a bank's fundamental value proposition and core service offerings to be - does a bank now have to articulate a clear social purpose as well as acknowledge its stakeholder obligations? It is important not to underestimate the role of aligning cultures, behaviors and rewards in a manner that is satisfactory to all stakeholders provided by industries other than banking are evolving rapidly and setting a high bar of expectation for banks to meet in the coming years. This raises important questions about how banks come to understand the costs of providing all of this in the rapidly evolving and costly regulatory environment of the future. Banks will be required by customers and regulators to do all of this in a transparent and fair manner and in a way that demonstrates the value they bring to customers. It requires a compelling proposition that also attracts an appropriate level of sustainable revenue. It raises questions about how banks will segment their available markets and determine what is core to their proposition. Big data capabilities will become increasingly important both to manage risk adequately and to serve, through micro personalization, their retail and corporate customers.

65 Takamura (2013) states that during the recent financial crisis in the U.S., banks reduced new business lending amidst concerns about borrowers' ability to repay. At the same time, firms facing higher borrowing costs alongside a worsening economic outlook reduced investment. To explain these aggregate business cycle patterns, he developed a model with households, banks and firms. He assumed that a bank's ability to raise deposits is constrained by a limited commitment problem and that, furthermore, loans to firms involve default risk. In this environment, changes in loan rates affect the size of the business sector. He explored how banks influence the behavior of households and firms and find that both productivity and financial shocks lead to counter-cyclical default and interest rate spreads. He examined the implications of a government capital injection designed to mitigate the effect of negative productivity and financial shocks in the spirit of the Troubled Asset Relief Program (TARP). He found that the stabilizing effect of such policy interventions hinges on the source of the shock. In particular, a capital injection is less effective against aggregate productivity shocks because easing banks' lending stance only weakly stimulates firms' demand for loans when aggregate productivity falls. In contrast, a capital injection can counteract the adverse effect of financial shocks on the supply of loans. This researcher measured aggregate productivity and financial shocks to evaluate the role of each in the business cycle. He found that the contribution of aggregate productivity shocks in aggregate output and investment is large until mid-2008. Financial shocks explain $65 \%$ of the fall in investment and 55\% of the fall in output in the first quarter of 2009.

66 Claessens, Horen (2013) states that over the past two decades, foreign banks have become much more important in domestic financial intermediation, heightening the need to understand their behavior. We introduce a new, comprehensive database, made publicly available, on bank ownership (including the home country of foreign banks) for 5,324 banks in 137 countries over the period 1995-2009. We document large increases in foreign bank presence in many countries, but with substantial heterogeneity in terms of host and banks' home countries, bilateral investment patterns, and bank characteristics. In terms of impact, we document that the relation between private credit and foreign bank presence importantly depends on host country and banks' characteristics. Specifically, foreign banks only seem to have a negative impact on credit in low-income countries, in countries where they have a limited market share, where enforcing contracts is costly and where credit information is limited available, and when they come from distant home countries. 
This shows that accounting for heterogeneity, including bilateral ownership, is crucial to better understand the implications of foreign bank ownership.

67 Saskia, Ewijk, et al. (2013) state that the two decades prior to the credit crisis witnessed a strategic shift from a traditional, relationships-oriented model (ROM) to a transactions-oriented model (TOM) of financial intermediation in developed countries. A concurrent trend has been a persistent decline in average bank interest margins. In the literature, these phenomena are often explained using a causality that runs from increased competition in traditional segments to lower margins to new activities. Using a comprehensive dataset with bank-level data on over 16,000 FDIC insured U.S. commercial banks for a period ranging from 1992 to 2010, this paper qualifies this chain of causality. It is found that a bank's business model, measured using a multidimensional proxy of relationship banking activity, exerts a robust, positive effect on interest margins. Relationship banks still enjoy considerable interest margins. Our results provide evidence that banks' quest for growth, not the level of competition in traditional retail segments, has transformed banks' balance sheets and has reduced interest rate margins as a by-product.

68 Prabhu (2013) states that the EXIM Bank is engaged in financing, facilitating and promoting India's two-way international trade and investment, and seeks to enhance the international competitiveness of Indian enterprises. Recognizing the dynamics of international trade, Exim Bank of India's vision has evolved beyond providing export credit to a conscious, systematic effort at creating international competitiveness capabilities by arranging competitive finance and services at all stages of the business cycle.

69 Maheswari (2013) states that an attempt has been made to review the performance of banking sector in India during post reform period. For this purpose banks have been broadly categorized into four categories: i. Foreign Sector Bank ii Private Sector Bank iii Nationalized Bank iv SBI and Associates A comparative appraisal of banks has been undertaken on the basis of four key indicators of financial performance namely: i Return on Investment ii Capital Asset Risk Weighted Ratio iii Business Per Employee iv Net Profitability Ratio. The analysis of the time period will be from 1994 to 2005. Latest trends and developments in the banking sector have also be discussed briefly. It is found that though public sector banks have improved considerably and their performance is comparable with banks in other sector yet they are lagging behind in thrust areas such as business per employee, profitability and asset quality etc.

70 Niepmann, Schmidt, et al. (2014) state that the banks play a critical role in international trade by providing trade finance products that reduce the risk of exporting. This paper employs two new data sets to shed light on the magnitude and structure of this business, which, as we show, is highly concentrated in a few large banks. The two principal trade finance instruments, letters of credit and documentary collections, covered about 10 percent of U.S. exports in 2012. They are preferred for larger transactions, which indicates the existence of substantial fixed costs in the provision and use of these instruments. Letters of credit are employed the most for exports to countries with intermediate degrees of contract enforcement. Compared to documentary collections, they are used for riskier destinations. We provide a model of payment contract choice that rationalizes these empirical findings, and we discuss implications for the ongoing provision of trade finance

71 Rani, Gaba (2014) state that now many types of banks are operating in India which provide many type of facility to people like providing loans, accepting deposits, e- banking, credit cards and ATM and Many types of norms have been made for banks like income recognition, BASEL 1, BASEL2, BASEL3, on the basis 
of which performance of banks is measured. Only number of branches and outstanding loans does not show the quality of banks because three words NPA is a virus because of which banks can liquidate .This study aims to compare the performance of private sector, public sector, foreign banks and scheduled commercial banks on the basis of NPA. For this advances are classified into different types and then comparison is made.From this study it is concluded that private sector banks are performing their job more efficiently than other banks.

72 Niepmann, Eisenlohr (2014) state that banks play a critical role in international trade by providing trade finance products that reduce the risk of exporting. This paper employs two new data sets to shed light on the magnitude and structure of this business, which, as we show, is highly concentrated in a few large banks. The two principal trade finance instruments, letters of credit and documentary collections, covered about 10 percent of U.S. exports in 2012. They are preferred for larger transactions, which indicates the existence of substantial fixed costs in the provision and use of these instruments. Letters of credit are employed the most for exports to countries with intermediate degrees of contract enforcement. Compared to documentary collections, they are used for riskier destinations. We provide a model of payment contract choice that rationalizes these empirical findings, and we discuss implications for the ongoing provision of trade finance.

73 Ramakrishna, Kurian (2014) state that the stability and viability of commercial banking is critical for economic growth and development. Non-performing asset management is a vital function to ensure that profitability is not compromised. This paper studies the core parameters in this context which are Gross Advances, Gross Non-performing assets, Net Advances and Net Nonperforming assets. The study has been done in respect of Foreign Banks and Public Sector Banks. The analysis is focused on comparing the performance of these two categories of banks with respect to Non-performing assets. Financial data for the years 2007-2012 has been used for this purpose.

74 Wignall, Atkinson et al., (2014) state that the main hallmarks of the global financial crisis were too-big-to-fail institutions taking on too much risk with other people's money: excess leverage and default pressure resulting from contagion and counterparty risk. This paper looks at whether the Basel III agreement addresses these issues effectively. Basel III has some very useful elements, notably a (much too light "back-up") leverage ratio, a capital buffer, a proposal to deal with pro-cyclicality through dynamic provisioning based on expected losses and liquidity and stable funding ratios. However, the paper shows that Basel risk weighting and the use of internal bank models for determining them leads to systematic regulatory arbitrage that undermines its effectiveness. Empirical evidence about the determinants of the risk in assessing of a bank (measured in this study by the Distance-to-Default) shows that a simple leverage ratio vastly outperforms the Basel Tier 1 ratio. Furthermore, business model features (after controlling for macro factors) have a huge impact. Derivatives origination, prime broking, etc., carry vastly different risks to core deposit banking. Where such differences are present, it makes little sense to have a one-size-fits-all approach to capital rules. Capital rules make more sense when fundamentally different businesses are separated.

75 Pedrotti (2014) examines the impact of the bank orientation on classical banking business, distinguishing between shareholder and stakeholder banks, and analyzes the preconditions for positive social welfare effects from the existence of stakeholder banks. For this reason we develop a theoretical bank decision model based on the utility approach and focus on the determination of the interest margin. Vis-à-vis previous studies, we connect to the recent literature on the agency view considering 
the lessons from recent financial developments. Moreover, we study the influence of the social mission on the bank pricing strategy, merging these two different fields for the first time. The results highlight the fundamental role of a strict and prudential regulation of the social mission as well as of the existence of internal and external control mechanisms, in order to avoid a misuse of stakeholder banks for distorting aims, to increase the system stability and to reduce market failures. Therefore, a correct implementation of these aspects represents a precondition for a positive contribution of stakeholder banks to the social welfare.

The FFIs model could be explained by all previously discussed model conceptualizations. However, in order to limit the FFIs model concept into a more manageable and study-related form, it is necessary to present a simplified FFIs model rationale. The purpose and target of the FFIs is an optimal financial performance. To achieve this, FFIs rely on a set of a few major processes: (1) acquisition of necessary funds for operating activities; (2) loan service provision as a means to generate revenues; and (3) risk taking. To manage these processes, FFIs develop their models - representations of how the organisation (a FFI) creates, delivers and captures value (Osterwalder, Pigneur 2010). As this study is focusing on economic value, the definition is further narrowed through a performance centric view.To account for competition and the different components optimal utilisation as the basis for FFIs models, a conceptualization similar to Afuah's is used. Afuah identified the FFIs model as a set of components utilized to achieve profits (Afuah 2004). For the purpose of a more tangible applicability and necessary FFIs model comparability, a work by Zott and Amit is used as a definition core for the FFIs model (Zott, Amit 2008). Applying similar conceptualization in the FFIs business, the acquisition of necessary funds, loan service provisions and implied risk-taking can be interpreted as a base financial product market strategy, as these are the same products/services that FFIs are competing for in the financial market. A FFI individually realized form and properties of these core activities combine unique models (e.g. a FFI acquires funding through retail sources (depositors) and uses it to issue housing loans maintaining relatively low risk levels). Therefore, a FFI model can be determined through the identification of how it does financial business; identifying funding strategies, the scope of activities and the nature of riskiness as determining variables. The FFIs model concept used in this study can be defined as: a representation of a set of components utilized to outperform the competition and to achieve optimal profit in a financial market where a similar product strategy is used. The evolutionary logic of the FFIs model is addressed by sympathizing with G. George's and A. Bock's thinking that organizations adjust and redesign their models under the effects of a changed operational environment (George, Bock 2011).

\section{Research Gap Analysis:-}

1 Scope of Review: - The effect of opening of economy on growth of a country and various models of Foreign Financial Institutions (FFIs) has been critically covered. There is also a difference of opinion related to adverse effect on host country's financial institutions due to entry of FFIs. Some researchers claim that it is the FFIs' working quality that helps to host country and not mere rate of interest. However in general, researchers point out that FFI is an important factor for the GDP growth. Openness to FFIs policy yields access to finance at a competitive rate.

2 Limitations of Review: - The effect of entry of FFIs in a host country from GDP growth point of view has been examined in detail. However, the effect of external financing from foreign financial institutions on working of domestic institutions is not examined. Also priority sector financing by FFIs is not critically examined. There is no unanimous acceptance amongst researchers about specific models of FFIs operating in host and home countries. 
3 Scope for further review work: - Effect of external financing from foreign financial institutions on working of domestic institutions may be reviewed in detail along with priority sector financing.

4 Conclusion: - Review of literature involved discussion in detail about various models used by FFIs although there is no unanimous acceptance amongst authors about specific models of FFIs operating in host and home countries. It also covers discussion related to growth involving innovation and financing by FFIs. It also covers discussion related to entry of FFIs on financial institutions from host countries. 